\title{
Lung Fluid Balance in Lambs before and after Premature Birth
}

Richard D. Bland, David P. Cartton, Richard G. Scheerer, James J. Cummings, and Dale L. Chapman

Cardiovascular Research Institute and Department of Pediatrics, University of California, San Francisco, California 94143

\begin{abstract}
The purpose of this study was to see if lung vascular protein permeability is greater in preterm lambs with respiratory distress than it is in lambs without lung disease. We measured pulmonary vascular pressures, lung lymph flow, and concentrations of protein in lymph and plasma of 10 chronically catheterized preterm lambs (gestation $133 \pm 1 \mathrm{~d}$ ) for $2-4 \mathrm{~h}$ before and for 4-8 $\mathrm{h}$ after delivery by cesarean section. All lambs were treated with mechanical ventilation after birth and received a constant intravenous infusion of glucose-saline solution at an hourly rate of $10 \mathrm{ml} / \mathrm{kg}$. Respiratory failure developed in six lambs, in which there was a sustained threefold postnatal increase in lung lymph flow and lymph protein flow, with an even greater increase in pleural liquid drainage. Concentrations of protein in lymph and pleural liquid were almost identical, averaging $\sim 75 \%$ of the plasma protein concentration. In the four preterm lambs without lung disease, lymph flow and lymph protein flow were either near or below fetal values by 6-8 h after birth, and there was little or no pleural liquid drainage. Extravascular lung water averaged $7.3 \pm .8 \mathrm{~g} / \mathrm{g}$ dry lung in lambs with respiratory failure compared to $4.8 \pm .5 \mathrm{~g} / \mathrm{g}$ dry lung in lambs without lung disease. Thus, pulmonary edema with abnormal leakage of protein-rich liquid from the lung microcirculation into the interstitium is an important pathological feature of the respiratory disease that often occurs after premature birth.
\end{abstract}

\section{Introduction}

Pulmonary edema is a consistent feature of the lung pathology associated with respiratory distress after premature birth (1-4). Previous studies have demonstrated the presence of abnormal lung epithelial protein leaks in both preterm infants (5) and lambs $(6,7)$ with severe respiratory distress. These protein leaks, which typically occur in terminal bronchioles (8), give rise to fibrin clots ("hyaline membranes") in the distal airspaces. There is also histological evidence of microvascular injury in the lungs of infants $(9,10)$ and lambs $(3)$ that die of respiratory failure after premature birth, but previous physiological studies have failed to document the presence of lung endothelial injury in this condition $(4,11,12)$.

Normand et al. (11) measured lung lymph flow before and after birth in anesthetized lambs and found that the postnatal increase in lymph flow was less in preterm animals with surfactant deficiency than it was in lambs with mature lungs. They interpreted this attenuated postnatal lymphatic response

Address reprint requests to Dr. R. D. Bland, Professor of Pediatrics, University of Utah School of Medicine, 50 North Medical Drive, Salt Lake City, UT 84132.

Received for publication 30 November 1988 and in revised form 2 March 1989.

J. Clin. Invest.

(c) The American Society for Clinical Investigation, Inc.

0021-9738/89/08/0568/09 \$2.00

Volume 84, August 1989, 568-576 as a sign of liquid retention within the lungs secondary to abnormal surface tension. These studies lasted only $2 \mathrm{~h}$ after birth, and subsequent experiments of a similar nature, but of longer duration, showed that lymph flow increased between 2 and $4 \mathrm{~h}$ after birth in preterm lambs, whereas it decreased during the same interval in mature lambs (12). Nevertheless, there was no significant difference between the two groups of lambs with respect to net lymph protein clearance over the entire 4-h period.

Sundell et al. (4) used a multiple indicator dilution method to estimate postnatal changes in extravascular lung water and pulmonary vascular permeability-surface area in lambs with respiratory distress after premature birth by cesarean section. Results were compared to data obtained from studies conducted with more mature lambs that did not have lung disease. Extravascular lung water was greater in lambs that had hyaline membrane disease than it was in control lambs. The estimated permeability-surface area product was significantly less in the distressed lambs than it was in the lambs without lung disease, a finding that these investigators attributed to decreased lung vascular surface area, presumably from "derecruitment" of portions of the pulmonary microcirculation in edematous and hypoxic areas of the lungs. Thus, despite the presence of protein-rich pulmonary edema and abnormal epithelial permeability in both lambs and humans that are born too soon, previous physiological studies have not demonstrated the presence of lung endothelial injury in respiratory distress after premature birth.

Because the pulmonary pathology of hyaline membrane disease evolves over a period of several hours after birth (13), we considered the possibility that a longer postnatal period of observation might provide a more reliable means of assessing differences in lung vascular protein permeability in preterm lambs with and without respiratory distress. We therefore extended the period of observation to $8 \mathrm{~h}$ after birth. We also thought that a chronic lymph fistula preparation would make it easier to distinguish lung liquid and protein leaks that occur as a result of acute surgery from liquid and protein leaks associated with lung injury after premature birth. Thus, we allowed several days for the fetuses to recover from surgery before studying them.

In preterm lambs with lung disease, there was a threefold increase in lung lymph flow and lymph protein flow, and an even greater increase in pleural liquid drainage during the postnatal period of observation. In preterm lambs without lung disease, lymph flow and protein flow were either near or below fetal values by 6-8 $\mathrm{h}$ after birth, and there was little or no pleural liquid drainage. These findings indicate that abnormal leakage of protein-rich liquid from the pulmonary microcirculation into the interstitium is an important feature in the pathogenesis of respiratory distress after premature birth.

\section{Methods}

Surgical preparation. We surgically prepared 10 fetal lambs, all singletons, at $126-132 \mathrm{~d}$ gestation (147 $\mathrm{d}$ is term). Suffolk and mixed breed 
sheep were mated on a specific day to allow precise assessment of gestational age. On the day of surgery, the ewes underwent spinal anesthesia with $1 \%$ tetracaine, supplemented with intravenous ketamine. As previously described (14), we opened the uterus through a midline abdominal incision, injected $1 \%$ xylocaine subcutaneously into a fetal hindlimb, and threaded polyvinyl catheters through an artery and vein into the fetal aorta and vena cava. Through a second uterine incision, we gave the fetus intramuscular ketamine and performed a right thoracotomy for placement of a catheter in the outflow duct of the caudal mediastinal lymph node, which in lambs receives one-half to two-thirds of total lung lymph $(14,15)$. The tail of the node was ligated just above the diaphragm to prevent contamination from nonpulmonary sources $(16,17)$, and a polyvinyl catheter $(1.27 \mathrm{~mm}$ i.d. and $2.29 \mathrm{~mm}$ o.d.) with multiple drainage holes was placed in the right pleural space. The lymphatic catheter was constructed to minimize outflow resistance (18): a $1-2-\mathrm{cm}$ polyvinyl segment $(0.28 \mathrm{~mm}$ i.d., $0.61 \mathrm{~mm}$ o.d.), sufficiently small to fit snugly within the lymphatic, was glued into a large-bore segment $(0.76 \mathrm{~mm}$ i.d., $1.27 \mathrm{~mm}$ o.d., $80 \mathrm{~cm}$ in length), the inner diameter of which was larger than that of the lymph vessel itself. The entire internal surface of this catheter was impregnated with heparin (TDMAC Processing; Polysciences, Inc., Warrington, PA) to prevent clotting. We did a left thoracotomy to place catheters directly into the pulmonary artery, left atrium, and pleural space. Another catheter was sutured to the outside of the chest, with its tip in the amniotic cavity, to provide a zero reference for subsequent vascular pressure measurements. We closed both thoracotomies with heavy silk sutures and tunneled the catheters through the uterine and abdominal incisions, which were doubly oversewn to prevent fluid leakage. We injected penicillin and kanamycin into the amniotic cavity $(1,000,000$ $U$ of penicillin and $400 \mathrm{mg}$ of kanamycin) and fetal vein $(300,000 \mathrm{U}$ of penicillin and $30 \mathrm{mg}$ of kanamycin) at the time of surgery and daily thereafter. The ewes also received $5 \mathrm{ml}$ of a mixture of penicillin and dihydrostreptomycin (Combiotic, $200,000 \mathrm{U} / \mathrm{ml}$ of procaine penicillin $\mathrm{G}$ and $250 \mathrm{mg} / \mathrm{ml}$ of dihydrostreptomycin sulfate; Pfizer Inc., New York) and $600 \mathrm{mg}$ kanamycin i.m. each day.

Experimental design. Experiments took place between 3 and $7 \mathrm{~d}$ after surgery, when the fetuses were healthy, as assessed by normal arterial blood gas tensions and $\mathrm{pH}$ measurements, and when their lymph was free of visible blood. With one exception (a lamb that died 4 h after birth), studies lasted a total of $10-12 \mathrm{~h}$ : a 2-4 h period of steady-state fetal measurements, followed by cesarean section under spinal anesthesia ( $1 \%$ tetracaine), and a 7-8 h period of measurements made during mechanical ventilation of the newborn lamb. We measured vascular, pleural, amniotic (for the in utero portion of the study), and airway (for the neonatal portion of the study) pressures through fluid-filled catheters connected to calibrated pressure transducers (BT3DC; Statham Instruments, Oxnard, CA) and an 8-channel amplifier-recorder (model 7D; Grass Instruments, Quincy, MA). Zero reference for vascular and pleural pressures was amniotic fluid pressure before birth and atmospheric pressure at the level of the left atrium after birth. We obtained samples of arterial blood hourly for measurement of hematocrit, $\mathrm{pH}, \mathrm{PaO}_{2}, \mathrm{PaCO}_{2}$, and plasma protein concentration. We collected lymph continuously in heparin-coated test tubes and took samples every $30 \mathrm{~min}$, measured their volume to the nearest $0.01 \mathrm{ml}$, and spun them in a centrifuge to obtain supernatant fluid for protein measurements. The distal tip of the lymph catheter was kept at a constant height, at or near the level of the left atrium. We gently aspirated as much liquid as possible from both pleural catheters every 10-15 min both before and after birth.

After a 2-4-h period of steady-state measurements (four consecutive 30-min intervals in which lung vascular pressures and lymph flow varied by $<10 \%$ ), we plugged the vascular and pleural catheters, gave spinal anesthesia with $1 \%$ tetracaine to the ewe, and delivered the lamb by cesarean section. We immediately inserted a $4.5-\mathrm{mm}$ cuffed endotracheal tube and began mechanical ventilation using a pressure-limited, time-cycled infant respirator (model 105 infant ventilator; Healthdyne, Marietta, GA). The lambs breathed $100 \% \mathrm{O}_{2}$, which was warmed $\left(34-37^{\circ} \mathrm{C}\right)$ and humidified with an in-line servo-controlled heater (Concha Therm III, model 380-80; Respiratory Care Inc., Arlington Heights, IL). Ventilator settings were: frequency $60 / \mathrm{min}$, inspiratory time $0.3 \mathrm{~s}$, gas flow rate $10-15$ liters/min, end-expiratory pressure 3-4 Torr, and peak inflation pressure sufficient to move the chest and ventilate the lungs, as assessed by measurement of arterial blood gas tensions and $\mathrm{pH}$. Immediately after birth, we reconnected the vascular and pleural catheters to their respective transducers and measured airway pressures from a T-piece inserted in the proximal end of the endotracheal tube.

We gave the animals intravenous morphine sulfate and pancuronium bromide (Pavulon, $1 \mathrm{mg} / \mathrm{ml}$; Organon, Inc., West Orange, $\mathrm{NJ}$ ), each at a dose of $0.1 \mathrm{mg} / \mathrm{kg}$ body wt every 3-4 h, to minimize discomfort and to facilitate ventilatory control. The lambs rested on a canvas sling beneath a radiant warmer (mobile infant warmer model MW78 IN; Air Shields, Hatboro, PA) and heating lamp, which were adjusted to maintain body temperature at $\sim 38^{\circ} \mathrm{C}$ (normal for a lamb). They received a continuous intravenous infusion of a warm solution containing sodium chloride (113 meq/liter), glucose (11.25 g/liter), and sodium bicarbonate $(25 \mathrm{meq} / \mathrm{liter})$ at an hourly rate of $10 \mathrm{ml} / \mathrm{kg}$ body $\mathrm{wt}$, and they also received penicillin $(100,000 \mathrm{U} / \mathrm{kg})$ and gentamicin $(2.5 \mathrm{mg} / \mathrm{kg})$ intravenously. We measured vascular, pleural, and airway pressures continuously, and collected samples of lymph and pleural liquid at 30-min intervals. In two lambs, the pulmonary artery catheter did not function after birth, and we therefore inserted a Swan-Ganz catheter through the jugular vein into the pulmonary artery using $1 \%$ xylocaine local anesthesia. Measurements were recorded every $30 \mathrm{~min}$, and data from four consecutive 30-min intervals were averaged for statistical comparison between lambs with and without lung disease and between time periods before and after birth.

From six lambs, three with and three without lung disease, we obtained samples of blood for total white cell and granulocyte counts during the $2 \mathrm{~h}$ immediately before and after birth, and the $2 \mathrm{~h}$ before death. White cell counts were measured with a Coulter counter (Coulter Electronics, Hialeah, FL) and granulocyte counts were determined from Wright's stained blood smears.

Postmortem studies. After 7-8 h (4 h in one animal) of mechanical ventilation, we intravenously injected pentobarbital sodium, $30 \mathrm{mg} / \mathrm{kg}$ body wt, rapidly split the sternum, aspirated blood from the heart, and clamped both hili at the prevailing peak airway pressure. We froze a piece of inflated lung in liquid nitrogen for subsequent microscopy and homogenized the remaining tissue for measurement of its blood and extravascular water content by a modification (19) of the method described by Pearce et al. (20).

Analytical methods. We centrifuged samples of lymph, blood, and pleural liquid, and measured the concentration of protein in the supernatant liquids by the biuret method (21). Cellulose acetate electrophoresis (Microzone 110; Beckman Instruments, Inc., Fullerton, CA) separated the protein fractions and allowed quantification of albumin and globulin. We measured the $\mathrm{pH}$ and partial pressures of $\mathrm{O}_{2}$ and $\mathrm{CO}_{2}$ in arterial blood on a blood gas analyzer (model 158; Corning Medical, Medfield, MA), with appropriate corrections for the prevailing body temperature.

Statistical analysis. Results in the text and tables are expressed as the mean \pm 1 SD. We used two-way analysis of variance to compare measurements made during the 2-h period before birth with measurements obtained during the $2 \mathrm{~h}$ immediately after birth and the $2 \mathrm{~h}$ before death. If analysis of variance showed a significant difference, $P$ $<0.05$, we then used the Fisher least significant difference test to compare data obtained during the specific time intervals (22). We applied Student's $t$ test for unpaired samples to compare data obtained from lambs that had lung disease vs. those that did not. For all statistical analyses, we regarded as significant those differences that were supported by a $P$ value of $<0.05$.

\section{Results}

Table I summarizes the status of the 10 lambs $(9$ males, 1 female) during the $2 \mathrm{~h}$ before birth. Six of the lambs suffered 
Table I. Summary Data for 10 Fetal Lambs, 0-2 $h$ before Birth

\begin{tabular}{|c|c|c|c|c|c|c|}
\hline & Gestational age & Birth weight & $\mathrm{pH}$ & $\mathrm{PaO}_{2}$ & $\mathrm{PaCO}_{2}$ & Hematocrit \\
\hline & $d$ & $k g$ & & Torr & Torr & $\%$ \\
\hline All lambs & $133 \pm 1^{*}$ & $3.6 \pm 0.7$ & $7.34 \pm 0.03$ & $18 \pm 5$ & $48 \pm 4$ & $34 \pm 5$ \\
\hline Six with respiratory distress ${ }^{\ddagger}$ & $133 \pm 2$ & $3.2 \pm 0.3$ & $7.33 \pm 0.03$ & $17 \pm 6$ & $48 \pm 4$ & $36 \pm 6$ \\
\hline Four without respiratory distress & $133 \pm 1$ & $4.2 \pm 0.7^{\S}$ & $7.35 \pm 0.01$ & $20 \pm 1$ & $49 \pm 4$ & $33 \pm 5$ \\
\hline
\end{tabular}

${ }^{*}$ Numbers are mean \pm SD. $\quad{ }^{\ddagger}$ Respiratory distress defined by postnatal course. ${ }^{\S}$ Significant differences between lambs with and without subsequent respiratory distress, $P<0.05$.

progressive respiratory failure after birth, documented by abnormal arterial blood gas tensions and increased requirements for ventilatory support. Physiological measurements before birth (Tables I and II) were not significantly different in these six lambs compared to the four lambs that had no apparent lung disease after birth. There was, however, a significant difference in body weight between lambs with $(3.2 \pm 0.3 \mathrm{~kg})$ and without $(4.2 \pm 0.7 \mathrm{~kg})$ subsequent lung disease. We were unable to aspirate pleural liquid before birth from five of the lambs; in five others (three with subsequent lung disease and two without), we obtained $2.7 \pm 1.0 \mathrm{ml} / \mathrm{h}$ of pleural liquid before delivery.

Lung lymph flow increased and the concentration of protein in lymph decreased after birth in all lambs (Figs. 1 and 2, Table III). During the first $2 \mathrm{~h}$ of ventilation, these changes were of similar magnitude in lambs with and without later lung disease. Pulmonary arterial pressure decreased and left atrial pressure increased after birth in the six lambs with evolving respiratory distress (Table III). Vascular pressures did not change significantly after birth in the four lambs with normal lung function, but the lymph/plasma protein concentration ratio decreased significantly in these lambs, perhaps the result of a shift of protein-poor liquid from the lung lumen into the interstitium. The only significant differences between the two groups of lambs during the first $2 \mathrm{~h}$ after birth were the lower $\mathrm{pH}$ and higher $\mathrm{PaCO}_{2}$ values in lambs that subsequently died of respiratory failure (Table IV). Differences in peak inflation pressure $(P=0.06)$ and hematocrit $(P=0.09)$ between the two groups also approached statistical significance.

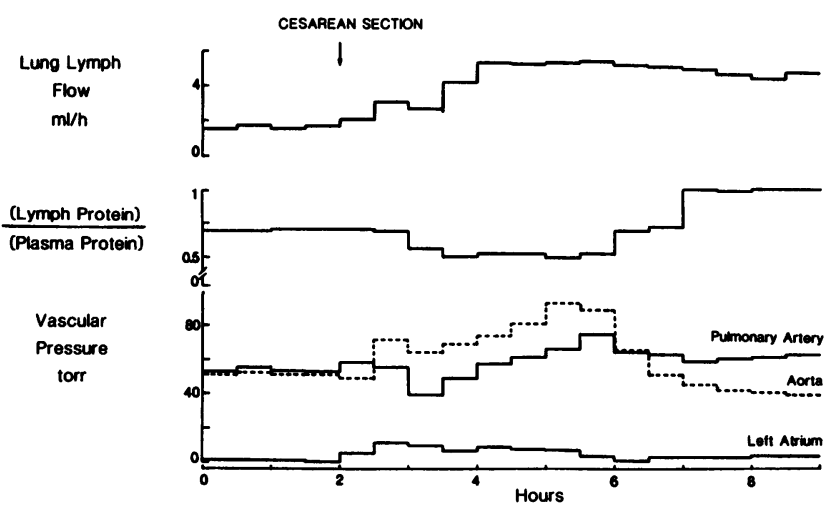

Figure 1. Time course of a study in one of six preterm lambs that died with evidence of severe lung disease. There was a sustained postnatal increase in lung lymph flow, associated with persistent pulmonary hypertension and a progressive increase in the lymph/ plasma protein concentration ratio. During the $2 \mathrm{~h}$ before death, systemic arterial blood pressure remained low.
Progressive acidosis and hypoxemia in lambs with lung disease led to increased ventilatory demands (higher peak inflation and mean airway pressures) during the last $2 \mathrm{~h}$ of study (Table V). Lambs with respiratory distress also had lower systemic arterial pressures and plasma protein concentrations than did lambs without lung disease (Figs. 1 and 2, Table VI), despite the fact that all lambs received the same volume of intravenous fluid per kilogram body weight. Hematocrit values also were higher in the lambs that had respiratory distress (Table V, $P=0.05$ ).

There was a sustained threefold increase in lung lymph flow and lymph protein flow (calculated as lymph flow $\times$ lymph protein concentration/plasma protein concentration) from birth until death in lambs with respiratory failure, whereas lymph flow and lymph protein flow were not significantly different from prenatal values by the end of the study in lambs without lung disease (Table VI). During the final 2-h interval, the concentration of protein in lymph relative to that in plasma averaged $0.75 \pm 0.24$ in lambs with respiratory failure, compared to $0.48 \pm 0.03$ in lambs with no lung disease $(P$ $=0.06)$. There were no significant differences in lymph or plasma albumin/globulin ratios between lambs with and without respiratory distress during any 2 -h time interval (data not shown).

Pleural liquid drainage occurred in all six lambs with lung disease, and the protein concentration of this liquid $(1.99 \pm 0.53 \mathrm{~g} / \mathrm{dl})$ was similar to that measured in lung lymph $(1.88 \pm 0.42 \mathrm{~g} / \mathrm{dl})$. The volume of pleural liquid collected hourly from these lambs averaged $6.75 \pm 4.85 \mathrm{ml}$, which was

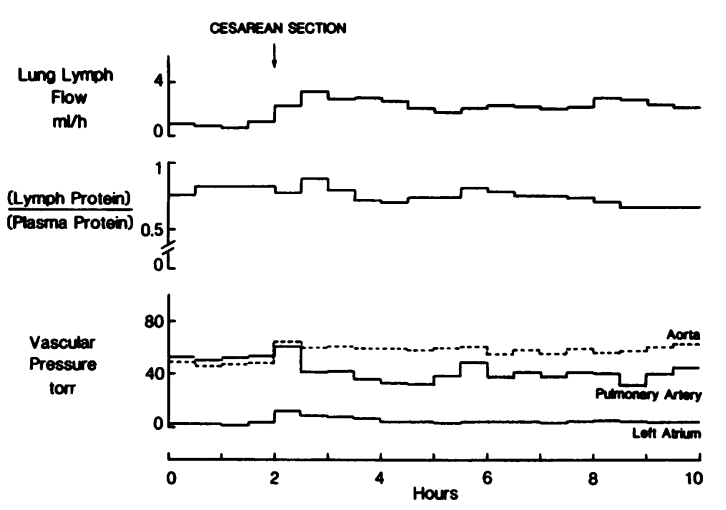

Figure 2. Time course of a study in one of four preterm lambs that had little or no evidence of lung disease. Pulmonary arterial pressure decreased after the onset of breathing, and there was an increase in lung lymph flow, associated with a reduction in lymph/plasma protein concentration ratio. Systemic arterial pressure increased after birth and remained constant throughout the study. 
Table II. Vascular and Pleural Pressures, Protein Concentrations, and Flow Rates of Lung Lymph and Lymph Protein in 10 Fetal Lambs during the $2 \mathrm{~h}$ before Birth

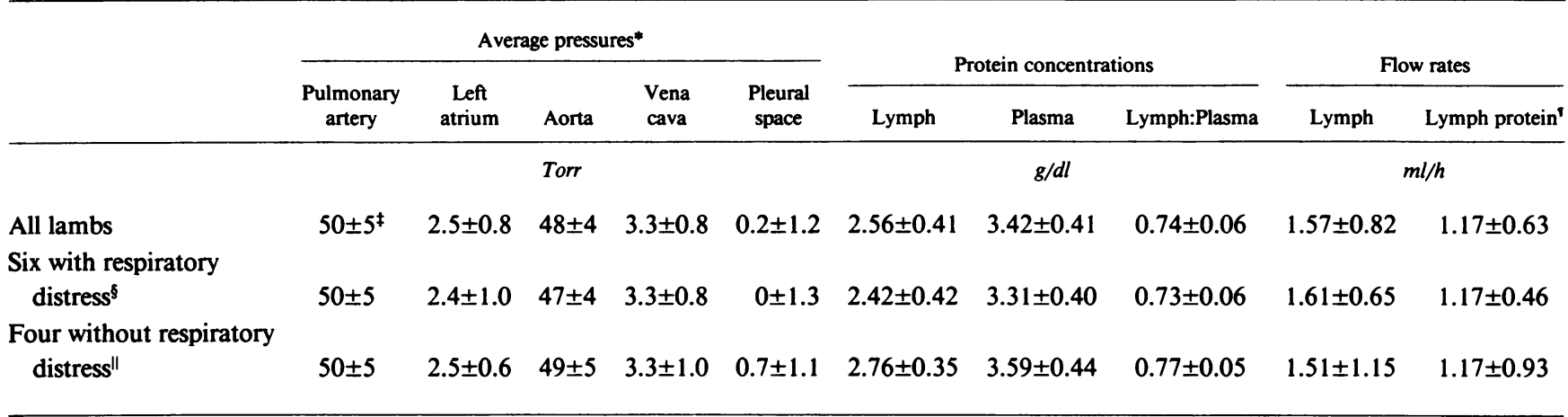

* Measured relative to amniotic liquid pressure. ${ }^{\ddagger}$ Numbers are mean \pm SD. ${ }^{\S}$ Respiratory distress defined by postnatal course. " No statistically significant differences between lambs with and without subsequent respiratory distress. 'Calculated as lymph flow $\times$ [lymph protein]/[plasma protein].

more than the volume of lymph collected hourly over the same time period. Pleural effusions were detected in only one of the four lambs without respiratory distress; that lamb also had unexplained pleural liquid drainage before birth and required postnatal placement of a Swan-Ganz catheter because of a nonfunctioning pulmonary artery catheter.

Total white cell and granulocyte counts in circulating blood decreased immediately after birth and then increased before death in all six lambs that had such measurements (Table VII). The pattern of change in white cell numbers after birth was not significantly different for lambs with and without lung disease.

Postmortem measurement of extravascular lung water averaged $7.32 \pm 0.82 \mathrm{~g} / \mathrm{g}$ dry lung tissue in lambs that died with respiratory failure, compared to $4.77 \pm 0.45 \mathrm{~g} / \mathrm{g}$ in lambs without lung disease $(P<0.001)$. The latter value is only slightly greater than the amount of extravascular water measured in lungs of lambs born vaginally near term (14). Light microscopy confirmed the presence of protein-rich edema in lungs of lambs that died with respiratory failure (Fig. 3).

\section{Discussion}

Pulmonary lymph flow and lymph protein flow before birth. Measurement of pulmonary lymph flow under steady-state conditions is a useful means of assessing net filtration of liquid from the microcirculation into the interstitium of the lungs in healthy newborn and adult sheep $(23,24)$. In fetal sheep, however, lung lymph flow accounts for only a small fraction of net liquid filtration, as most of the liquid that flows out of the fetal pulmonary circulation passes directly into potential air spaces because of active secretion of chloride ion across the lung epithelium (25). In lambs near term, hourly secretion of liquid into the lung lumen averages 4-5 $\mathrm{ml} / \mathrm{kg}$ body wt (26), whereas hourly lung lymph flow averages $0.39 \mathrm{ml} / \mathrm{kg}$ body weight (14). In our 10 preterm lambs, pulmonary lymph flow averaged $0.45 \pm 0.20(\mathrm{ml} / \mathrm{h}) / \mathrm{kg}$ body wt during the $2-\mathrm{h}$ steady-state period before birth. Thus, changes in lung maturation that occur in fetal lambs late in gestation are not associated with an appreciable change in pulmonary lymph flow.
Whereas lung lymph flow constitutes only a small fraction of the liquid that flows out of the pulmonary microcirculation in fetal lambs, lymph protein clearance closely reflects net transvascular protein movement, as liquid collected from the lung lumen contains $<0.3 \mathrm{mg} / \mathrm{ml}$ of protein (27). Lymph protein clearance before birth in our 10 preterm lambs averaged $0.33 \pm 0.15(\mathrm{ml} / \mathrm{h}) / \mathrm{kg}$ body $\mathrm{wt}$, compared to an average of $0.31(\mathrm{ml} / \mathrm{h}) / \mathrm{kg}$ body $\mathrm{wt}$ in lambs that we previously studied late in gestation (14). The ratio of albumin concentration to globulin concentration in lymph relative to the same ratio in plasma is an index of differential protein sieving in the pulmonary microcirculation (28). This ratio averaged $1.53 \pm 0.31$ before birth in our preterm lambs, compared to $1.57 \pm 0.38$ in our previous studies of more mature lambs. These findings suggest that lung vascular permeability to protein is similar in preterm and term fetal lambs studied under comparable steady-state conditions.

Liquid and protein clearance through lung lymphatics. This investigation focused on perinatal changes in lung fluid balance of preterm lambs delivered by cesarean section. One of our goals was to see if there might be differences in lung liquid clearance and associated respiratory function associated with lung maturation. Compared to previous studies done with lambs that were born vaginally close to term (14), we expected that the absence of labor would lengthen the duration of lung liquid clearance and possibly accentuate the lymphatic component of this process. We also thought that preterm lambs with incomplete lung development might show evidence of pulmonary microvascular injury and edema. Earlier studies had shown that postnatal lung lymph flow and lymph protein clearance were less in preterm lambs than in mature lambs, but these were acute experiments that lasted only $2 \mathrm{~h}$, during which the placental circulation was intact $(11,15)$. As lung liquid clearance normally requires more than $2 \mathrm{~h}$, we extended the postnatal period of observation to $6-8 \mathrm{~h}$ in order to assess liquid and protein dynamics in the pulmonary circulation beyond the anticipated period of luminal liquid absorption. 6 of 10 lambs suffered progressive respiratory failure after birth; 4 lambs had little or no evidence of lung disease, as assessed by satisfactory respiratory gas exchange and diminishing requirements for ventilatory support during the postnatal period.

Lung lymph flow increased and lymph protein concentra- 
Table III. Vascular Pressures, Protein Concentrations, Lymph Flow, and Lymph Protein Flow for the First 2 h after Birth in Six Lambs with and Four Lambs without Subsequent Respiratory Distress

\begin{tabular}{|c|c|c|c|c|c|c|c|c|c|}
\hline \multirow{3}{*}{$\begin{array}{l}\text { Respiratory } \\
\text { distress }\end{array}$} & \multicolumn{4}{|c|}{ Average pressures* } & \multicolumn{3}{|c|}{ Protein concentrations } & \multirow{2}{*}{\multicolumn{2}{|c|}{ Flow rates }} \\
\hline & Pulmonary & Left & & Pleural & & & & & \\
\hline & artery & atrium & Aorta & space & Lymph & Plasma & Lymph:Plasma & Lymph & Lymph protein' \\
\hline & \multicolumn{4}{|c|}{ Torr } & \multicolumn{3}{|c|}{$g / d l$} & \multicolumn{2}{|c|}{$m l / h$} \\
\hline+ & $37 \pm 9 \neq 8$ & $7 \pm 2^{\S}$ & $47 \pm 8$ & $2 \pm 2$ & $1.93 \pm 0.35^{\S}$ & $3.23 \pm 0.57$ & $0.60 \pm 0.08$ & $4.46 \pm 2.46^{\S}$ & $2.73 \pm 1.78^{\S}$ \\
\hline- & $40 \pm 17^{\prime \prime}$ & $5 \pm 3$ & $53 \pm 9$ & $3 \pm 2$ & $1.69 \pm 0.18^{\S}$ & $3.33 \pm 0.38$ & $0.52 \pm 0.10^{\S}$ & $3.50 \pm 1.96^{\S}$ & $1.88 \pm 1.36$ \\
\hline
\end{tabular}

* Measured relative to atmospheric pressure. ${ }^{\ddagger}$ Numbers are mean \pm SD. ${ }^{\S}$ Significant difference compared to corresponding measurements made during $2 \mathrm{~h}$ before birth, $P<0.05$. "No statistically significant differences between lambs with and without subsequent respiratory distress. ' Calculated as lymph flow $\times$ [lymph protein]/[plasma protein].

tion decreased when mechanical ventilation began in all 10 lambs. For the six lambs with progressive respiratory failure, it is difficult to ascertain how much of their lung luminal liquid drained by way of lymphatics because of their abnormal lung vascular liquid and protein leak. In the four lambs without apparent lung disease, the total volume of excess lymph collected during the 4-8-h period after birth (i.e., the amount in excess of prenatal lymph flow) averaged $8.24 \mathrm{ml}$, or $1.98 \mathrm{ml} / \mathrm{kg}$ body wt. At the same time, net lymph protein flow increased by $55 \%$. Because liquid in the lung lumen at birth contained very little protein, it is likely that the postnatal increase in net lymph protein flow was mainly the result of an increase in liquid filtration from the vasculature. If we therefore assume that the pulmonary circulation was the source of $55 \%$ of the postnatal increase of lymph flow in our four healthy preterm lambs, i.e., that $45 \%$ of the increase came from displacement of luminal liquid, then the estimated volume of luminal liquid that drained after birth via the lymphatics was $3.7 \mathrm{ml}$, or 1.17 $\mathrm{ml} / \mathrm{kg}$ body wt. If we also assume that we were collecting onehalf of total lung lymph, a conservative estimate according to previous measurements of the thoracic duct component of lung lymph (15), which is what we collect, then the postnatal increase in lymph flow for these four lambs averaged $2.34 \mathrm{ml}$ of liquid/kg body wt. Postmortem extravascular lung water content in these same animals was $4.8 \mathrm{~g} / \mathrm{g}$ dry lung (dry lung wt was $10.4 \mathrm{~g}$ ), compared to $12.3 \mathrm{~g} / \mathrm{g}$ dry lung in normal fetal lambs without labor (14). From these figures, we calculate that our four lambs without respiratory distress shed $\sim 78 \mathrm{ml}$ of water, or $24.7 \mathrm{ml} / \mathrm{kg}$ body wt from their lungs after birth. Thus, our results indicate that in healthy preterm lambs, as in mature lambs (14), pulmonary lymphatics drain $\sim 10 \%$ of the residual liquid in the lungs at birth.

Lung lymph protein drainage (lung lymph flow $\times$ lymph protein concentration/plasma protein concentration) increased in all 10 preterm lambs during the first $2 \mathrm{~h}$ after birth. In contrast, previous studies of a similar nature, conducted with more mature lambs that were born vaginally, showed no significant postnatal increase in lymph protein clearance (14). There are several possible explanations for this difference. First, newborn lambs that are born prematurely have higher lung vascular pressures and lower plasma protein osmotic pressures than term lambs have. There is also evidence that alveolar liquid pressure, which approximates perimicrovascular interstitial pressure (29), may be less in preterm than in term lungs (30). These findings might account for greater transvascular filtration of fluid and bulk flow of protein into the lungs of the less mature animals. The lower lymph/plasma protein ratio observed soon after birth of preterm lambs, compared to term lambs, is consistent with this explanation. Another possibility is that pulmonary blood flow and microvascular surface area for fluid exchange may increase to a greater extent after premature birth by cesarean section than after vaginal birth close to term. This is an unlikely explanation, however, because of the high pulmonary vascular resistance and greater amount of liquid in the lungs of lambs that are born prematurely compared with those that are born at term (4). A third possibility is that lung vascular protein permeability is greater immediately after birth in preterm lambs than it is in mature lambs, although previous investigators have not found evidence for this $(11,12,15)$.

Table IV. Summary Data for the First $2 \mathrm{~h}$ after Birth in Six Lambs with and Four Lambs without Subsequent Respiratory Distress

\begin{tabular}{|c|c|c|c|c|c|c|c|}
\hline \multirow[b]{2}{*}{$\begin{array}{l}\text { Respiratory } \\
\text { distress }\end{array}$} & \multirow[b]{2}{*}{ Hematocrit } & \multirow[b]{2}{*}{$\mathrm{pH}$} & \multirow[b]{2}{*}{$\mathrm{PaO}_{2}^{*}$} & \multirow[b]{2}{*}{$\mathrm{PaCO}_{2}$} & \multicolumn{3}{|c|}{ Airway pressures } \\
\hline & & & & & Peak inflation & Mean airway & End expiration \\
\hline & $\%$ & & & & Torr & & \\
\hline+ & $41 \pm 9^{\ddagger}$ & $7.22 \pm 0.06^{8}$ & $109 \pm 76^{\S}$ & $47 \pm 12$ & $34 \pm 8$ & $13 \pm 4$ & $4 \pm 2$ \\
\hline- & $33 \pm 2$ & $7.43 \pm 0.06^{\prime \prime}$ & $205 \pm 133^{\S}$ & $29 \pm 3^{811}$ & $24 \pm 5$ & $9 \pm 1$ & $4 \pm 1$ \\
\hline
\end{tabular}

* $\mathrm{PaO}_{2}$ breathing $100 \% \mathrm{O}_{2}$. ${ }^{\ddagger}$ Numbers are mean $\pm \mathrm{SD}$. ${ }^{\$}$ Significant difference compared to corresponding measurements made during $2 \mathrm{~h}$ before birth, $P<0.05$ (airway pressures not compared to before birth). "Significant difference between lambs with and without subsequent respiratory distress, $P<0.05$. 
Table V. Summary Data for Hematocrit, Respiratory Gas Exchange, Airway and Pleural Pressures in Lambs with and without Lung Disease in the Last 2 h of Study

\begin{tabular}{|c|c|c|c|c|c|c|c|c|}
\hline \multirow[b]{2}{*}{$\begin{array}{l}\text { Respiratory } \\
\text { distress }\end{array}$} & \multirow[b]{2}{*}{ Hematocrit } & \multirow[b]{2}{*}{$\mathrm{pH}$} & \multirow[b]{2}{*}{$\mathrm{PaO}_{2}{ }^{*}$} & \multirow[b]{2}{*}{$\mathrm{PaCO}_{2}$} & \multicolumn{3}{|c|}{ Airway pressures } & \multirow[b]{2}{*}{$\begin{array}{l}\text { Mean pleural } \\
\text { pressure }\end{array}$} \\
\hline & & & & & Peak inflation & Mean airway & End expiration & \\
\hline & & & \multicolumn{6}{|c|}{ Torr } \\
\hline+ & $46 \pm 10^{\ddagger}$ & $7.22 \pm 0.06^{\ddagger}$ & $48 \pm 22$ & $46 \pm 6$ & $38 \pm 10$ & $14 \pm 4$ & $4 \pm 2$ & $2 \pm 2^{\S}$ \\
\hline - & $34 \pm 5^{\prime \prime}$ & $7.41 \pm 0.05^{\prime \prime}$ & $287 \pm 107^{ \pm \mid 14}$ & $33 \pm 2^{\ddagger 11}$ & $19 \pm 4^{\| !}$ & $7 \pm 1^{111}$ & $4 \pm 1$ & $1 \pm 1$ \\
\hline
\end{tabular}

* $\mathrm{PaO}_{2}$ breathing $100 \% \mathrm{O}_{2}$. ${ }^{\ddagger}$ Significant difference compared to corresponding measurements made during $2 \mathrm{~h}$ before birth, $P<0.05$ (airway pressures not compared to before birth). ${ }^{\S}$ Numbers are mean \pm SD. "Significant difference between values for lambs with and without respiratory distress, $P<0.05$. 'Significant difference compared to corresponding measurements made during $2 \mathrm{~h}$ immediately after birth, $P<0.05$.

Postnatal changes in the systemic circulation. After birth, plasma protein concentration decreased over time in the six preterm lambs that had respiratory distress. In part, this probably reflects the relatively large amount $(10 \mathrm{ml} / \mathrm{kg}$ body $\mathrm{wt})$ of intravenous fluid that the lambs received. These infusions were necessary to reduce the degree of hemoconcentration (progressive rise in hematocrit) and hypotension that often develop in lambs that are delivered prematurely. Some of the reduction in plasma protein concentration, particularly in the sicker animals, may have been the result of a systemic vascular protein leak. The postnatal increase in hematocrit observed in some of the lambs, and the postmortem finding of ascites in some of the sicker animals, are consistent with the possibility that a generalized plasma protein leak may have contributed to the progressive hypoproteinemia that developed in the lambs that acquired severe lung disease. Loss of plasma from the circulation also may have contributed to the persistently low systemic blood pressure observed in these lambs. It is noteworthy that systemic arterial blood pressure increased after birth in the four lambs with normal lung function. Moreover, there was no significant postnatal decrease in plasma protein concentration in these animals. Thus, hypotension and hypoproteinemia, which often accompany severe respiratory distress in human infants $(31,32)$, may reflect abnormal leakage of plasma from the systemic circulation, similar to that which occurs in the lungs.

Lung microvascular injury in preterm lambs with respiratory failure. During the $2 \mathrm{~h}$ before death, lung lymph flow and lymph protein flow were significantly greater in lambs with lung disease than they were in lambs without lung disease. There was nearly a fourfold difference in lymph protein flow and an even greater difference in pleural liquid drainage between lambs with and without respiratory failure. The most plausible explanation for these differences is that lung vascular protein permeability was increased in the sicker animals. It is unlikely that pulmonary microvascular surface area was greater in the lambs that had severe lung disease, as previous studies by Sundell et al. (4) suggested that lung vascular surface area for fluid exchange is reduced in preterm lambs with respiratory distress, perhaps because of pulmonary vasoconstriction from hypoxia and edema. Increased filtration pressure in the pulmonary circulation also can influence the flow of liquid and protein into the lungs, but such an effect should be associated with a reduction in lymph protein concentration relative to plasma protein concentration, which did not occur in the lambs with respiratory distress. Moreover, there were no significant differences in pulmonary arterial and left atrial pressures between the two groups of animals during the last $2 \mathrm{~h}$ of study. Thus, the results are most consistent with abnormal lung vascular protein permeability in the presence of a relatively high fluid filtration pressure, with secondary impairment of fetal lung liquid drainage and development of protein-rich pulmonary edema.

These findings are similar to those that have been described in the adult counterpart of respiratory distress syndrome after intravenous infusion of Escherichia coli endotoxin (33), microemboli (34), or oleic acid (35). Our findings of protein-rich pleural effusions and lung edema in preterm lambs with respi-

Table VI. Vascular Pressures, Protein Concentrations, Lung Lymph Flow and Protein Flow in Lambs with and without Respiratory Distress in the Last $2 h$ of Study

\begin{tabular}{|c|c|c|c|c|c|c|c|c|c|}
\hline \multirow{3}{*}{$\begin{array}{l}\text { Respiratory } \\
\text { distress }\end{array}$} & \multicolumn{4}{|c|}{ Average vascular pressures } & \multirow{2}{*}{\multicolumn{3}{|c|}{ Protein concentrations }} & \multirow{2}{*}{\multicolumn{2}{|c|}{ Flow rates }} \\
\hline & \multirow{2}{*}{$\begin{array}{c}\text { Pulmonary } \\
\text { artery }\end{array}$} & \multirow{2}{*}{$\begin{array}{c}\text { Left } \\
\text { atrium }\end{array}$} & \multirow[b]{2}{*}{ Aorta } & \multirow{2}{*}{$\begin{array}{l}\text { Vena } \\
\text { cava }\end{array}$} & & & & & \\
\hline & & & & & Lymph & Plasma & Lymph:Plasma & Lymph & Lymph protein* \\
\hline & & \multicolumn{2}{|c|}{ Torr } & & \multicolumn{2}{|c|}{$g / d l$} & & \multicolumn{2}{|c|}{$\mathrm{ml} / \mathrm{h}$} \\
\hline+ & $43 \pm 12^{\ddagger \S}$ & $5 \pm 1^{8 \|}$ & $45 \pm 10$ & $4 \pm 1$ & $1.57 \pm 0.29^{\S}$ & $2.21 \pm 0.54^{8 \|}$ & $0.75 \pm 0.24$ & $4.82 \pm 2.06^{\S}$ & $3.41 \pm 1.25^{\S}$ \\
\hline- & $36 \pm 5$ & $4 \pm 2$ & $62 \pm 8^{8 \mid 14}$ & $5 \pm 1$ & $1.54 \pm 0.24^{\S}$ & $3.22 \pm 0.45^{\prime}$ & $0.48 \pm 0.02^{8}$ & $1.86 \pm 1.49^{\mid 14}$ & $0.88 \pm 0.67^{114}$ \\
\hline
\end{tabular}

* Calculated as lymph flow $\times$ [lymph protein]/[plasma protein]. ${ }^{\ddagger}$ Numbers are mean \pm SD. ${ }^{\S}$ Significant difference compared to corresponding measurements made during $2 \mathrm{~h}$ before birth, $P<0.05$. "Significant difference compared to corresponding measurements made during $2 \mathrm{~h}$ immediately after birth, $P<0.05$. 'Significant difference between values for lambs with and without respiratory distress, $P<0.05$. 
Table VII. White Cell and Granulocyte Counts in Blood Obtained before and after Birth from Six Lambs, Three with and Three without Respiratory Distress

\begin{tabular}{|c|c|c|c|}
\hline $\begin{array}{l}\text { Respiratory } \\
\text { distress }\end{array}$ & Time period & White cell count & Granulocyte count \\
\hline & & \multicolumn{2}{|c|}{ Cells $/ \mu l$} \\
\hline & Before birth & $2,947 \pm 1,589$ & $1,276 \pm 860^{* \neq \S}$ \\
\hline \multirow[t]{3}{*}{+} & $0-2 \mathrm{~h}$ after birth & $1,200 \pm 503$ & $248 \pm 126$ \\
\hline & Before death & $2,623 \pm 2,296$ & $990 \pm 478$ \\
\hline & Before birth & $3,931 \pm 1,106$ & $1,449 \pm 346$ \\
\hline \multirow[t]{2}{*}{-} & $0-2 \mathrm{~h}$ after birth & $2,472 \pm 1,437$ & $904 \pm 556$ \\
\hline & Before death & $4,108 \pm 1,648$ & $1,928 \pm 1,596$ \\
\hline
\end{tabular}

\section{* Numbers are mean \pm SD.}

${ }^{\ddagger}$ No significant differences between lambs with and without respiratory distress.

$\S$ In all six lambs, both the white cell count and the granulocyte count decreased after birth and then increased before death.

ratory failure show that changes in lung lymph flow and lymph protein clearance probably underestimate the amount of liquid entering the lungs in conditions associated with severe lung microvascular injury.

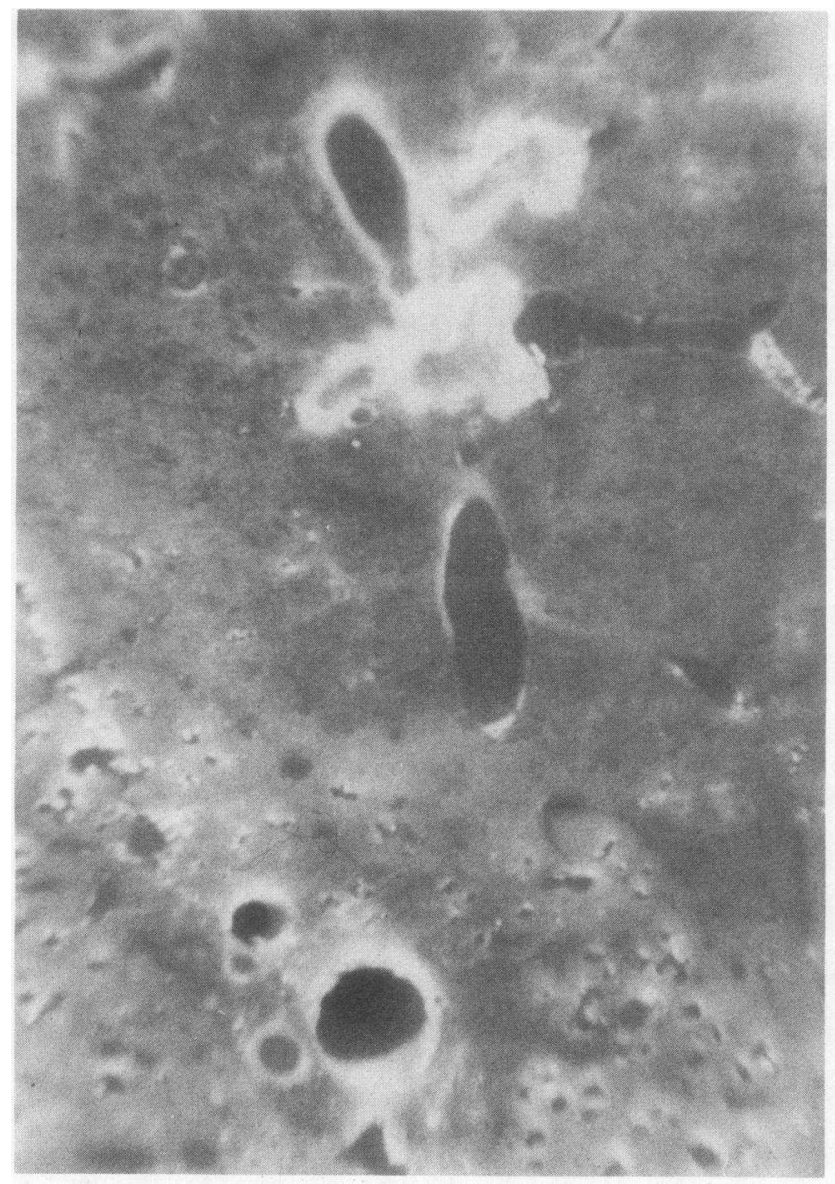

Previous studies have shown that intravenous injection of live bacteria (36) or bacterial toxin $(33,37)$ may cause an increase in lung lymph flow and lymph protein flow, similar to the changes that occurred after birth in six of our preterm lambs. It is unlikely, however, that infection led to the increase in lung vascular permeability of these lambs, as all sheep, including fetuses, received therapeutic doses of broad spectrum antibiotics from the time of surgery until death. Moreover, when the studies began all lambs were healthy, as assessed by normal arterial blood pH, $\mathrm{PaO}_{2}$, and $\mathrm{PaCO}_{2}$, and there were no significant postnatal differences in white blood cell or granulocyte counts, heart rate, or body temperature between lambs with and without lung disease.

It is difficult to know how much of the lung microvascular injury in our lambs was the result of their underlying disease and how much may have been the result of therapeutic intervention. Mechanical ventilation with high inflation pressures and tidal volumes can cause abnormal protein leakage in the pulmonary circulation of otherwise healthy animals $(38,39)$. It is possible that preterm lambs with incomplete lung development are especially vulnerable to the stress of positive pressure breathing. In addition, several studies have shown that prolonged oxygen breathing may lead to lung microvascular injury in young lambs (40-42). While this endothelial damage usually requires at least $3 \mathrm{~d}$ of sustained hyperoxia in healthy

Figure 3. Photomicrographs of frozen sections of lung obtained from a preterm lamb with diffuse atelectasis and pulmonary edema (left), and from a preterm lamb without physiological evidence of lung disease (right). 
animals, such injury might occur sooner in preterm lambs with deficient defenses against oxidant stress. It is also important to point out that in the presence of an abnormal pulmonary microcirculation, a generous supply of intravenous salt and water may have contributed to lung edema formation and the need for greater ventilator support in six of our preterm lambs, though four of the lambs appeared to tolerate these intravenous infusions without apparent ill effects.

Summary. We have shown that lambs with incomplete lung development after premature birth have a sustained threefold increase in lung lymph flow and lymph protein flow, and an even greater increase in pleural liquid drainage, indicative of severe pulmonary microvascular injury. These postnatal changes were associated with impaired respiratory gas exchange and acidosis, increased demands for ventilator support, a decrease in plasma protein concentration with an associated increase in hematocrit, and a persistently low systemic arterial blood pressure. Abnormal lung vascular protein permeability and pulmonary edema, are important features in the pathogenesis of respiratory distress after premature birth in lambs.

\section{Acknowledgments}

The authors thank A. Westgate, D. Lindsey, and R. Shanks for their technical assistance, and J. Alfstad for typing the manuscript.

This work was supported in part by National Heart, Lung and Blood Institute grants HL-25816 and HL/HD-24056. D. P. Carlton received support from HD-07162 and D. L. Chapman was supported in part by grants from the Giannini Foundation, the American Lung Association, and HL-07893.

\section{References}

1. DeSa, D. J. 1969. Pulmonary fluid content in infants with respiratory distress. J. Pathol. 97:469-479.

2. Lauweryns, J. M. 1965. Hyaline membrane disease: a pathological study of 55 infants. Arch. Dis. Child. 40:618-625.

3. Stahlman, M., V. S. LeQuire, W. C. Young, R. E. Merrill, R. T. Birmingham, G. A. Payne, and J. Gray. 1964. Pathophysiology of respiratory distress in newborn lambs. Am. J. Dis. Child. 108:375-393.

4. Sundell, H. W., T. R. Harris, J. R. Cannon, D. P. Lindstrom, R. Green, J. Rojas, and K. L. Brigham. 1987. Lung water and vascular permeability-surface area in premature newborn lambs with hyaline membrane disease. Circ. Res. 60:923-932.

5. Gitlin, D., and J. M. Craig. 1956. The nature of the hyaline membrane in asphyxia of the newborn. Pediatrics. 17:64-71.

6. Jobe, A., M. Ikegami, H. Jacobs, S. Jones, and D. Conaway. 1983. Permeability of premature lamb lungs to protein and the effect of surfactant on that permeability. J. Appl. Physiol. 55:169-176.

7. Jobe, A., H. Jacobs, M. Ikegami, and D. Berry. 1985. Lung protein leaks in ventilated lambs: effect of gestational age. J. Appl. Physiol. 58:1246-1251.

8. Nilsson, R., G. Grossman, and B. Robertson. 1978. Lung surfactant and the pathogenesis of neonatal bronchiolar lesions induced by artificial ventilation. Pediatr. Res. 12:249-255.

9. Van Breemen, V. L., H. B. Neustein, and P. D. Bruns. 1957. Pulmonary hyaline membranes studied with the electron microscope. Am. J. Pathol. 33:769-789.

10. Campiche, M., S. Prod'hom, and A. Gautier. 1961. Etude au microscope electronique du poumon de prematures morts en destress respiratoire. Ann. Pediatr. 196:81-95.

11. Normand, I. C. S., E. O. R. Reynolds, L. B. Strang, and J. S.
Wigglesworth. 1968. Flow and protein concentration of lymph from lungs of lambs developing hyaline membrane disease. Arch. Dis. Child. 43:334-339.

12. Sundell, H. W., J. Rojas, J. Grogaard, P. Mohan, B. Englehardt, A. Van der Abbeele, T. R. Harris, and K. L. Brigham. 1985. Lung lymph studies in newborn lambs with hyaline membrane disease. In Physiological Development of the Fetus and Newborn. C. T. Jones and P. W. Nathanielsz, editors. Academic Press, London. 331-335.

13. Gandy, G., W. Jacobson, and D. Gairdner. 1970. Hyaline membrane disease. I. Cellular changes. Arch. Dis. Child. 45:289-310.

14. Bland, R. D., T. N. Hansen, C. M. Haberkern, M. A. Bressack, T. A. Hazinski, J. U. Raj, and R. B. Goldberg. 1982. Lung fluid balance in lambs before and after birth. J. Appl. Physiol. 53:992-1004.

15. Humphreys, P. W., I. C. S. Normand, E. O. R. Reynolds, and L. B. Strang. 1967. Pulmonary lymph flow and the uptake of liquid from the lungs of the lamb at the start of breathing. J. Physiol. (Lond.). 193:1-29.

16. Chanana, A. D., and D. D. Joel. 1986. Contamination of lung lymph following standard and modified procedures in sheep. J. Appl. Physiol. 60:809-816.

17. Drake, R. R., G. A. Laine, S. J. Allen, J. Katz, and J. C. Gabel. 1986. Over-estimation of sheep lung lymph contamination. J. Appl. Physiol. 61:1590-1592.

18. Drake, R., M. Giesler, G. Laine, J. Gabel, and T. Hansen. 1985. Effect of outflow pressure on lung lymph flow in unanesthetized sheep. J. Appl. Physiol. 58:70-76.

19. Erdmann, A. J., III, T. R. Vaughan, Jr., K. L. Brigham, W. C. Woolverton, and N. C. Staub. 1975. Effect of increased vascular pressure on lung fluid balance in unanesthetized sheep. Circ. Res. 37:271284.

20. Pearce, M. L., J. Yamashita, and J. Beazell. 1965. Measurement of pulmonary edema. Circ. Res. 16:482-488.

21. Henry, R. J., C. Sobel, and S. Berkman. 1957. Interferences of biuret methods for serum protein; use of Benedict's qualitative glucose reagent as a biuret reagent. Anal. Chem. 29:1491-1495.

22. Koopmans, L. H. 1987. Introduction to Contemporary Statistical Methods. 2nd edition. Duxbury Press, Boston, MA. 301-369.

23. Bland, R. D., and D. D. McMillan. 1977. Lung fluid dynamics in awake newborn lambs. J. Clin. Invest. 60:1107-1115.

24. Staub, N. C. 1971 . Steady state pulmonary transvascular water filtration in unanesthetized sheep. Circ. Res. 28/29(Suppl. 1):135-139.

25. Olver, R. E., and L. B. Strang. 1974. Ion fluxes across the pulmonary epithelium and the secretion of lung liquid in the foetal lamb. J. Physiol. (Lond.). 241:327-357.

26. Mescher, E. J., A. C. G. Platzker, P. L. Ballard, J. A. Kitterman, J. A. Clements, and W. H. Tooley. 1975. Ontogeny of tracheal fluid, pulmonary surfactant, and plasma corticoids in the fetal lamb. J. Appl. Physiol. 39:1017-1021.

27. Adamson, T. M., R. D. H. Boyd, H. S. Platt, and L. B. Strang. 1969. Composition of alveolar liquid in the foetal lamb. J. Physiol. (Lond.). 204:159-168.

28. Bressack, M. A., D. D. McMillan, and R. D. Bland. 1979. Pulmonary oxygen toxicity: increased microvascular permeability to protein in unanesthetized lambs. Lymphology. 12:133-139.

29. Fike, C. D., S. J. Lai-Fook, and R. D. Bland. 1988. Alveolar liquid pressures in newborn and adult rabbit lungs. J. Appl. Physiol. 64:1629-1635.

30. Raj, J. U. 1987. Alveolar liquid pressure measured by micropuncture in isolated lungs of mature and immature fetal rabbits. $J$. Clin. Invest. 79:1579-1588.

31. Neligan, G. A., D. M. Oxon, and C. A. Smith. 1960. The blood pressure of newborn infants in asphyxial states and in hyaline membrane disease. Pediatrics. 26:735-744.

32. Bland, R. D. 1972. Cord-blood total protein level as a screening aid for the idiopathic respiratory-distress syndrome. N. Engl. J. Med. 287:9-13.

33. Brigham, K. L., R. Bowers, and J. Haynes. 1979. Increased 
sheep lung vascular permeability caused by E. coli endotoxin. Circ. Res. 45:292-297.

34. Malik, A. B., and H. van der Zee. 1978. Lung vascular permeability following progressive embolization. J. Appl. Physiol. 45:590597.

35. Wiener-Kronish, J. P., V. C. Broaddus, K. H. Albertine, M. A. Gropper, M. A. Matthay, and N. C. Staub. 1988. The relationship of pleural effusions to increased permeability pulmonary edema in anesthetized sheep. J. Clin. Invest. 82:1422-1424.

36. Brigham, K. L., W. C. Woolverton, L. H. Blake, and N. C. Staub. 1974. Increased sheep lung vascular permeability caused by pseudomonas bacteremia. J. Clin. Invest. 54:792-804.

37. Sandberg, K., B. Engelhardt, C. Hellerqvist, and H. Sundell. 1987. Pulmonary response to group B streptococcal toxin in young lambs. J. Appl. Physiol. 63:2024-2030.

38. Dreyfuss, D., P. Soler, G. Basset, and G. Saumon. 1988. High inflation pressure pulmonary edema. Am. Rev. Respir. Dis. 137:1159-1164.

39. Carlton, D. P., R. G. Scheerer, J. J. Cummings, and R. D. Bland. 1988. Lung overexpansion injures the pulmonary microcirculation in lambs. Pediatr. Res. 23:500a. (Abstr.)

40. Bressack, M. A., D. D. McMillan, and R. D. Bland. 1979. Pulmonary oxygen toxicity: increased microvascular permeability to protein in unanesthetized lambs. Lymphology. 12:133-139.

41. Hansen, T. N., T. A. Hazinski, and R. D. Bland. 1982. Vitamin $\mathrm{E}$ does not prevent oxygen-induced lung injury in newborn lambs. Pediatr. Res. 16:583-587.

42. Hazinski, T. A., K. A. Kennedy, M. L. France, and T. N. Hansen. 1988. Pulmonary $\mathrm{O}_{2}$ toxicity in lambs: physiological and biochemical effects of endotoxin infusion. J. Appl. Physiol. 65:15791585. 